\title{
The Effect of Replacement of Soybean Meal with Lupine Seed (Lupinus albus vr. Energy) on Growth Performance and Carcass Traits in Turkeys
}

\author{
Daniel MIERLITA* \\ Department of Animal Science, University of Oradea, Romania \\ *Corresponding author, e-mail: dadi.mierlita@yahoo.com \\ Bulletin UASVM Animal Science and Biotechnologies 71(2) / 2014, \\ Print ISSN 1843-5262; Electronic ISSN 1843-536X \\ DOI:10.15835/buasvmcn-asb:10379
}

\begin{abstract}
This research has been conducted to check to what extent soybean meal in the turkey broilers meals can be replaced partially by alkaloid free lupine seeds, monitoring the effect of this important alternative source of protein on the production performance, carcass quality and on the economic efficiency. The experiment was made as a fully randomized experimental design which consisted of four treatments which involved a control diet consisting of corn-soybean meal (LC) and three experimental diets (i.e. E1, E2 and E3 lots) in which protein from soybean meal were replaced with alkaloids free lupine flour. White lupine beans (vr. Energy - alkaloids free variety) obtained in specific climatic conditions of the Western Romania, after grinding, were introduced in the structure of mixed fodder at a rate of 20\% (in the lot E1), 30\% (in the lot E2) and 40\% (in the lot E3). Substituting soybean protein meals in turkey broilers by inserting alkaloids free white lupine beans in the structure of mixed fodder at a rate of up to $30 \%$ (\% by weight) has no adverse effect on the following: weight gain, degree of food recovery, slaughter and carcass quality indices. A significant reduction $(\mathrm{p}<0.05)$ of the performance has been found in broilers from the lot E3, where white lupine seeds were introduced in the mixed fodder at a rate of $40 \%$. In comparison with the control group, the final weight of turkey broilers from the lot E3 was lower by $7.80 \%$, the feed intake was lower by 3.71\%, the feed consumption per $1 \mathrm{~kg}$ gain in weight was higher by $4.42 \%$, and the chest share in the carcass structure was lower by 1.54 percentage points. As against the control lot (LC), in the case of the experimental groups the price of one $\mathrm{kg}$ of mixed forage decreased by $14.02 \%$ and the feed costs per $1 \mathrm{~kg}$ gain in weight decreased by $10.78 \%$ (i.e. the case of the turkey broilers in group E2 where food the lupine seeds accounted for $30 \%$ - in $\%$ by weight of feed). The increase of lupine seeds share in the structure of mixed fodder up to $40 \%$ ensure a significant reduction of feed costs per achieving a gain of a single $\mathrm{kg}$ (by $10.2 \%$ as compared to control lot), but because of the significant reduction in the average weight of turkeys at slaughter age (by approx. $1.5 \mathrm{~kg} /$ turkey versus control group), we assess that this is not an optimal solution for feeding turkey broilers.
\end{abstract}

Keywords: alkaloid-free lupine, protein, turkey

\section{INTRODUCTION}

In the context of the prohibition of animal flours in the poultry diet and the high price of soybean products and by-products, the lupine seeds can be a promising alternative for the provisioning from domestic production of plant protein in feeding poultry in our country. Climatic conditions of our country provide the prerequisites for obtaining a proper lupine seeds production both in terms of quantity and quality (Mierlita, 2012).

In Romania, the cultivation and especially the use of white lupine seeds to feeding poultry is not promoted to the same extent as in other countries, although it is a viable alternative to soy grits from imports, both in bio-productive terms as well as economically and environmentally. From an environmental approach, white lupine seeds have the advantage that they are not genetically modified, and because they can fix atmospheric nitrogen, for fertilization purposes they require small amounts of chemical fertilizers, and thus it is considered as a sustainable culture with positive outcomes on soil fertility and the environment (Vecerek et al., 2008). 
The interest in using lupine seeds in broilers diets is justified primarily by its high protein content $(40.08 \% \mathrm{~Pb}$.), but also by its high-energy value (2658 kcal EM/ kg) (Mierlita, 2012). Most studies have shown that, by introducing lupine in shares of up to $25 \%$ in broilers meals one reaches similar results to those provided by diets based on soybean meal Brenes et al., 1993; Lettner and Zollitsch 1995; Sitko and Cermac, 1998; Egorov et al., 2001; Nalle et al., 2010; Suchy et al., 2010; Mierlita D., 2012). Mierlita, (2012) concluded that in order to maintain growth performance of broilers, lupine flour can be inserted into broilers food to a maximum of $30 \%$ and lupine cannot fully substitute soy grits within the diet of broiler chickens.

The use of lupine as the sole source of protein for poultry is limited on the one hand by the biological value of protein (low content in methionine, lysine, tryptophan and threonine -Strakova et al., 2006), and the high content in NAP (non amidine polyglucides) which adversely affects the processes of digestion and recovery of food (Kocker et al., 2000). Increasing the recovery degree of lupine in broiler nutrition can be achieved by using specific enzyme preparations or by shelling the beans, when the latter can substitute $50 \%$ of the soy grits used in combined forage structure without modifying the bio performance of broilers (Suchy et al., 2010).

The research has been conducted to check to what extent soybean meal in the turkey broilers meals can be replaced partially by alkaloid free lupine seeds, monitoring the effect of this important alternative source of protein on the production performance, carcass quality and on the economic efficiency.

\section{MATERIAL AND METHODS}

The experiment was made as a fully randomized experimental design, which consisted of four treatments which involved a control diet consisting of corn - soybean meal (LC) and three experimental diets (i.e. E1, E2 and E3 lots) in which protein from soy grits were replaced with alkaloids free lupine flour. This alternative source of protein for feeding turkey broilers was included in the structure of mixed fodder at a rate of $20 \%$ (in the lot E1), $30 \%$ (in the lot E2) and 40\% (in the lot E3); thus the lupine seeds substitute up to $77 \%$ (stage $0-3$ weeks), 81\% (phase 3-9 weeks), 97\% (stage 9-12 weeks) and $100 \%$ (after 12 weeks until slaughter) of proteins provided by soybean grits (Tab. 1).

In our experiment, we used Energy variety white lupine seeds (improved in France), cultivated in the climatic conditions of the Western Romania, using seeds imported from Netherlands. All diets were formulated to contain similar levels of metabolisable energy, crude protein and limiting amino acids (lysine and methionine + cystine), providing hybrid specific nutritional requirements.

A total of 36 broiler turkeys, male, aged one day (Grade Maker Hybrid, imported from Austria) were divided randomly into four lots. The dynamics of body mass was based on the individual weighing of broilers from each group when populating (one day) and during the breeding period, i.e. at the age of $3,6,12$ and 18 weeks when the productive experiments were concluded.

Feed was administered at discretion, the amount of feed consumed was determined for each broilers lot and that for each breeding period (0-3, 3-6, 6-12 and 12-18 weeks, respectively) through weighting.

In order to determine the economic efficiency of the partial substitution of soybean grits in the turkey broiler feed with Lupine, we calculated the total costs. In order to calculate the price of one $\mathrm{kg}$ of feed, by growth stages individually, we considered raw material prices recorded in December 2013 on the free market. As an indicator of economic efficiency we considered the feed costs per $1 \mathrm{~kg}$ increase in weight, given that all other costs were the same in all broilers lots (the one day old broilers value, heating costs and microclimate conditions related costs, labor costs, veterinary actions costs, etc.).

At the age of 18 weeks and in order to assess the quantitative and qualitative indicators of meat

Tab. 1. Experimental design

\begin{tabular}{|c|c|c|}
\hline Group & Treatment & \multirow{5}{*}{$\begin{array}{l}\text { Effect of lupine seeds on the main indices of production and } \\
\text { consumption (gain in weight, feed use); } \\
\text { Effect of lupine seeds on feed related costs relative to } 1 \mathrm{~kg} \\
\text { increase in weight; } \\
\text { Effect of lupine seeds on the main slaughter indices and carcass } \\
\text { quality (yield at slaughter, the share of main parts cut out of the } \\
\text { carcass). }\end{array}$} \\
\hline LC & Soybean meal & \\
\hline$E_{1}$ & Lupine seeds - $\mathbf{2 0 \%}$ & \\
\hline $\mathbf{E}_{2}$ & Lupine seeds - $\mathbf{3 0 \%}$ & \\
\hline & Lupine seeds $-40 \%$ & \\
\hline
\end{tabular}


production, seven broilers were slaughtered from each, eliminating the minus variants of the lot. At control slaughter the following indices were determined: carcass mass, edible internal organs mass, slaughter yield, mass of the main parts cut out of the carcass and the share of intra-abdominal and adherent fat in the carcass' structure.

Testing the significance of the differences between groups was made by applying ANOVA testing (Pall, 2007). Differences were declared as being significant at $\mathrm{p}<0.05$.

\section{RESULTS AND DISCUSSION}

Out of the analysis of data on the evolution of body mass of turkey broilers, presented in Table 2 we can draw the following conclusions:

At the age of one day (when populating) the weight of broilers was almost equal in all lots;

At the age of 3 weeks, the average weight of broilers was almost equal to the broilers in the control lot in which food it was used only soybean grits as protein forage with the broilers in the lots E1 and E2 in which food lupine seeds were introduced at a rate of $20 \%$ and $30 \%$, respectively, and significantly lower in broilers in group E3 $(\mathrm{p}<0.05)$ in which the lupine seeds were supplied in feeding at a rate of $40 \%$, thus substituting $77.5 \%$ of the protein provided by the soy grits;
At the age of 6, 12 and 18 weeks there were recorded similar aspects to those previously reported; it is once again remarkable the significantly lower weight $(\mathrm{p}<0.01)$ of the broilers from the lot E3 as against the control lot and even against the broilers in the groups E1 and E2 where lupine was $20 \%$ and $30 \%$, respectively, of the food structure;

The final weight of the experimental broilers recorded at the age of 18 weeks was between $19.87 \mathrm{~kg} /$ head in case of control lot LC and 18.32 $\mathrm{kg} /$ in the case of the lot E3. Unlike broilers from the control lot LC, which recorded the highest final body weight, the body weight was less by $0.28 \mathrm{~kg}$ $(1.41 \%)$ in lot E1; $0.80 \mathrm{~kg}(4.03 \%)$ in lot E2 and $1.55 \mathrm{~kg}(7.80 \%)$ in lot E3, the differences being statistically significant only for the lot E3 $(\mathrm{p}<0.01)$.

Based on the results achieved we can asses that substituting soy protein grits with white lupine flour does not have a significant effect $(p>0.05)$ on the value and the dynamics of turkey broiler's body weight, provided that the share of lupine seeds in the structure of mixed fodder does not exceed 30\% (in the case of lot E1 and E2). Increasing the share of lupine seeds in the structure of mixed fodder over $30 \%$ (\% of the feed weight) has a negative impact on weight gain, thus $r$ educing significantly $(\mathrm{p}<0.05)$ the average body

Tab. 2. The effect of partial substitution of soybean grits with white lupine seeds on turkey broiler weight gain.

\begin{tabular}{|c|c|c|c|c|}
\hline & \multicolumn{4}{|c|}{ Groun } \\
\hline & $\begin{array}{c}\text { LC } \\
X \pm \mathrm{s} X\end{array}$ & $\begin{array}{c}\mathbf{E}_{1} \\
X \pm \mathrm{S} X\end{array}$ & $\begin{array}{c}\mathbf{E}_{2} \\
X \pm \mathrm{S} X\end{array}$ & $\begin{array}{c}\mathbf{E}_{3} \\
X \pm \mathrm{S} X\end{array}$ \\
\hline \multicolumn{5}{|c|}{ a) Evolution of body weight (g/capita) } \\
\hline 1 day & $50.7 \pm 0.02$ & $51.1 \pm 0.01$ & $50.4 \pm 0,03$ & $50.1 \pm 0.01$ \\
\hline 3 week & $691.8 \pm 0.31$ & $697.6 \pm 0.50$ & $672.7 \pm 0,37$ & $653.2 \pm 0.41^{*}$ \\
\hline 6 week & $2.70 \pm 0.11$ & $2.78 \pm 0.09$ & $2.68 \pm 0,14$ & $2.50 \pm 0.12^{*}$ \\
\hline 12 week & $9.27 \pm 0.20$ & $9.20 \pm 0.17$ & $8.87 \pm 0,19$ & $8.33 \pm 0.14^{* *}$ \\
\hline 18 week & $19.87 \pm 0.28$ & $19.59 \pm 0.32$ & $19.07 \pm 0,25$ & $18.32 \pm 0.35^{* *}$ \\
\hline \multicolumn{5}{|c|}{ b) Average total gain } \\
\hline $0-3$ week (g) & 641.1 & 646.5 & 622.3 & 603.1 \\
\hline 3-6 week (g) & 2.012 & 2.086 & 2.010 & 1.849 \\
\hline 6-12 week (g) & 6.570 & 6.418 & 6.190 & 5.830 \\
\hline 12-18 week (g) & 10.600 & 10.388 & 10.197 & 9.989 \\
\hline Total gain (kg) & 19.819 & 19.539 & 19.020 & 18.270 \\
\hline \multicolumn{5}{|c|}{ c) Average daily gain } \\
\hline $0-3$ week & 30.52 & 30.78 & 29.63 & 28.72 \\
\hline 3-6 week & 95.79 & 99.32 & 95.73 & 88.02 \\
\hline 6-12 week & 156.43 & 152.81 & 147.37 & 138.80 \\
\hline 12-18 week & 252.29 & 247.34 & 242.79 & 237.82 \\
\hline Average (0-18 week) & 157.29 & 155.07 & 150.95 & 145.00 \\
\hline
\end{tabular}


Tab. 3. The effect of partial substitution of soybean grits with white lupine seeds on feed consumption.

\begin{tabular}{|c|c|c|c|c|c|}
\hline \multirow{2}{*}{ Group } & \multicolumn{4}{|c|}{ g feed/day/bird } & \multirow{2}{*}{$\begin{array}{c}\text { Average for the } \\
\text { period (0-18 } \\
\text { week) }\end{array}$} \\
\hline & $0-3$ week & 3-6 week & 6-12 week & 12-18 week & \\
\hline $\mathrm{LC}$ & 46.1 & 162.3 & 364.0 & 788.7 & 419.0 \\
\hline$E_{1}$ & 47.1 & 172.1 & 359.9 & 766.8 & 412.1 \\
\hline $\mathrm{E}_{2}^{1}$ & 45.3 & 168.9 & 346.5 & 764.1 & 405.9 \\
\hline $\mathrm{E}_{2}^{2}$ & 45.6 & 160.5 & 333.5 & 773.9 & 403.5 \\
\hline
\end{tabular}

LC - Control; E1 - 20\% lupin seed; E2 - 30\% lupin seed; E3 - 40\% lupin seed.

weight of turkey broilers when reaching slaughter age (in the case of the lot E3).

The provisioning of lupine flour in large proportions in turkey broilers' food (i.e. $40 \%$ in the case of the lot E3) had a negative impact on feed intake but also on the degree of recovery of the food (Tab. 3 and Fig. 1). Thus, the daily feed intake relative to the entire experimental period, decreased in the lots to which food it was introduced lupine flour compared with control group, by up to $3.7 \%$. Moreover, the average consumption of mixed forage to achieve one kilo in weight based on the whole growth period (018 weeks) was almost equal to that recorded in the control group, the experimental lots E1 and E2

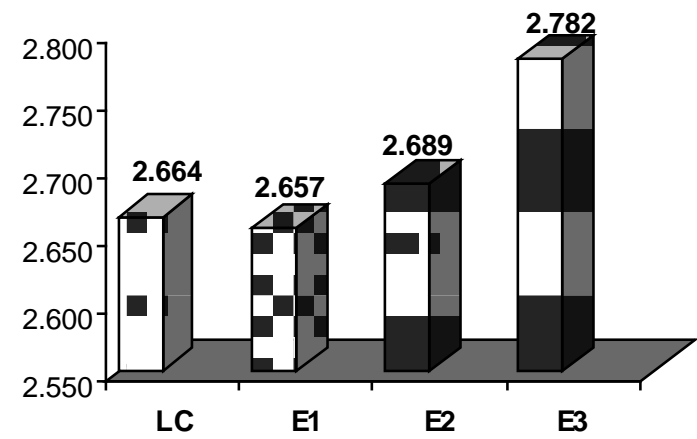

Fig. 1. The effects of alkaloids free white lupine seeds on the food recovery degree.

to which Lupine seeds were within $30 \%$ of food structure and increased by $4.43 \%$ when lupine accounted for $40 \%$ of mixed fodder structure (in the case of the group E3).

The provisioning of alkaloids free white lupine seeds in the structure of mixed fodder for the turkey broilers food by stages in a share of up to $30 \%$ (as \% of feed) is recommended without adverse effects on weight gain, consumption and the degree of food recovery. Increasing the proportion of lupine in food to $40 \%$ (in the group E3) has significantly reduced $(p<0.01)$ the final weight of broilers and feed intake and increased the consumption of specific mixed forage per $1 \mathrm{~kg}$ gain in weight.

In most studies published in the international literature it is mentioned that the provisioning of lupine seeds in broiler food in the amount of up to $250 \mathrm{~g} / \mathrm{kg}$ (without shelling the seeds without using enzyme preparations) does not affect the growth performance and feed recovery if the diet is balanced in essential amino acids and mainly in sulfur amino acids (Teixeira and Dos, 1995; Olver and Jonker, 1997; Roth-Maier and Paulicks, 2003), considering that the amount of sulfur amino acids in lupine seeds are just $1 / 3$ of that found in soybean grits ( 0.5 vs. $1.5 \mathrm{~g} / 100 \mathrm{~g}$ protein, Sujak et al., 2006). Provisioning lupine beans in the diet of chicken broilers, in shares exceeding 35\%, reduce their production performance (Roth-Maier and Paulicks 2003 Steenfeld et al., 2003); the negative influence of lupine is attributed to the large amounts of NAP (non amidine polyglucides).

Despite its high fat content, the lupine has a low energy value due to the high content in NAP (Kocker et al., 2000). It was calculated that for every percentage of lupine in the diet of broilers, its energy value decreases by $0.288 \mathrm{MJ} \mathrm{ME} /$ kg (Sipsas and Glencross, 2005) and by adding specific enzymes in food, the apparent digestibility of energy increased by 3.2 percentage points (Froidmont et al., 2004) and the use of proteins and amino acids improves (Nalle, 2009).

Analyzing the influence of partial substitution of soybean grits in the food of broilers with lupine flour on the average cost price of the mixed fodder, one can perceive the net superiority of the lot E3 in which food it was used the highest proportion of lupine i.e. 40\% (Tab. 4). Thus, in comparison with the control lot (LC), in the case of experimental lots, the price per $1 \mathrm{~kg}$ of mixed forage decreased by up to $14.02 \%$ and the broilers feed costs dropped by up to $17.23 \%$.

Introducing lupine seeds in the food of turkey broiler at a rate of $30 \%$ and a corresponding 
Tab. 4. The impact of provisioning white lupine on the price of feed and feed costs per $1 \mathrm{~kg}$ weight gain

\begin{tabular}{|c|c|c|c|c|}
\hline & $\mathrm{LC}$ & E1 & $\mathrm{E} 2$ & E3 \\
\hline $\begin{array}{c}\text { Fodder cost (RON/kg)* } \\
\text { Feeding costs (RON/bird) }(0-18\end{array}$ & 1.612 & 1.491 & 1.425 & 1.386 \\
\hline $\begin{array}{c}\text { week): } \\
\text { - RON } \\
\%\end{array}$ & $\begin{array}{c}85.111 \\
-\end{array}$ & $\begin{array}{c}77.403 \\
90.94\end{array}$ & $\begin{array}{c}72.874 \\
85.62\end{array}$ & $\begin{array}{c}70.442 \\
82.76\end{array}$ \\
\hline $\begin{array}{l}\text { Feeding costs (RON/kg gain) } \\
\text { Differences from LC: - RON/kg }\end{array}$ & $\begin{array}{c}4.294 \\
-\end{array}$ & $\begin{array}{r}3.961 \\
-0.333\end{array}$ & $\begin{array}{r}3.831 \\
-0.463\end{array}$ & $\begin{array}{r}3.856 \\
-0.438\end{array}$ \\
\hline$-\%$ & - & -7.75 & -10.78 & -10.20 \\
\hline
\end{tabular}

LC - Control; E1 - 20\% lupin seed; E2 - 30\% lupin seed; E3 - 40\% lupin seed.

* Specific prices for the month of December, 2013.

reduction in the share of soybean grits resulted in lower feed costs per $1 \mathrm{~kg}$ gain in weight by $10.78 \%$ and $0.463 \mathrm{RON} / \mathrm{kg}$ gain, thus totaling savings of approx. 9 RON on each slaughtered turkey. Increasing the share of lupine in the structure of mixed fodder to $40 \%$, ensuring a significant reduction in feed costs for achieving $1 \mathrm{~kg}$ gain (by $10.2 \%$ as compared to control lot), but due to significant reduction in the average weight of turkeys at slaughter age (with approx. $1.5 \mathrm{~kg} /$ turkey from the control group), we assess that this is not an optimal solution for feeding broiler turkeys.

The results of control slaughter conducted at the end of the breeding period are shown in Table 5. The indicators analyzed shows generally statistical differences only in the broilers in the lot E3, in which food the highest proportion of lupine was provisioned. The highest values of slaughter indices submitted for analysis were recorded in the control lot (LC) and the lowest in the lot E3, while in the case of the lots E1 and E2 there were recorded values very close to those found in broilers from the lot in which food it was used only soybean grits as a source of vegetable protein. These results lead to the conclusion that lupine seeds can be added in the structure of mixed fodder to feed in stages the turkey broilers in a share of up to $30 \%$; the shares of white lupine exceeding $30 \%$ in the fodder play a negative impact on carcass features. Thus, compared to the control lot LC, the carcass yield was lower by 1.52 percentage points (i.e. 72.47 vs. $71.37 \%$ ) in the case of broilers from the lot E3 and differences were statistically based $(\mathrm{p}<0.05)$.

Except for the chest share in the carcass structure, which recorded significantly lower values in lot E3 $(p<0.05)$ in comparison with the other lots, the remaining portions cut from the carcass showed no significant differences in the experimental lots compared to control lot.

The results of our study show that inclusion of lupine flour in large proportions in the food of

Tab. 5. The impact of partial substitution of soybean grits with white lupine seeds on main indices of slaughter and carcass quality of turkey broiler $(n=7)$.

\begin{tabular}{|c|c|c|c|c|}
\hline & \multicolumn{4}{|c|}{ Group } \\
\hline & $\begin{array}{c}\text { LC } \\
X \pm s \mathrm{x}\end{array}$ & $\begin{array}{l}\text { E1 } \\
X \pm s x\end{array}$ & $\begin{array}{l}E 2 \\
X \pm s x\end{array}$ & $\begin{array}{l}\text { E3 } \\
X \pm s x\end{array}$ \\
\hline \multicolumn{5}{|c|}{ a) Evolution of the main indicators of slaughterhouse } \\
\hline The weight (kg) & $19.38 \pm 0.34$ & $19.12 \pm 0.54$ & $18.76 \pm 0.37$ & $18.11 \pm 0.12^{*}$ \\
\hline Carcass weight (kg) & $14.05 \pm 0.21$ & $13.92 \pm 0.33$ & $13.61 \pm 0.18$ & $12.92 \pm 0.47^{*}$ \\
\hline The yield of the casing (\%) & $72.47 \pm 0.57$ & $72.82 \pm 0.89$ & $72.54 \pm 0.72$ & $71.37 \pm 1.07^{*}$ \\
\hline Edible offal (heart, gizzard, & $2.24 \pm 0.11$ & $2.14 \pm 0.17$ & $2.10 \pm 0$ & $2.79 \pm 0.14^{*}$ \\
\hline Commercial yield (\%) & $74.71 \pm 0.62$ & $74.96 \pm 0.76$ & $74.64 \pm 0.64$ & $74.16 \pm 0.55$ \\
\hline \multicolumn{5}{|c|}{ b) Share the trans main housing ( $\%$ of carcass weight) } \\
\hline Chest (\%) & $37.08 \pm 2.05$ & $37.66 \pm 1.12$ & $36.43 \pm 0.77$ & $35.54 \pm 1.21^{*}$ \\
\hline Chicken drumsticks (\%) & $17.59 \pm 0.67$ & $18.32 \pm 0.91^{*}$ & $18.74 \pm 0.52^{*}$ & $17.30 \pm 0.61$ \\
\hline Thighs (\%) & $12.70 \pm 0.39$ & $12.89 \pm 0.61$ & $13.06 \pm 0.39$ & $12.47 \pm 0.84$ \\
\hline Wings (\%) & $10.93 \pm 0.27$ & $11.57 \pm 0.38$ & $11.87 \pm 0.30$ & $11.60 \pm 0.52$ \\
\hline Fat deposit & $2.24 \pm 0.11$ & $2.14 \pm 0.17$ & $2.10 \pm 0.12$ & $2.79 \pm 0.14^{*}$ \\
\hline
\end{tabular}

LC - Control; $E_{1}-20 \%$ lupin seed; $E_{2}-30 \%$ lupin seed; $E_{3}-40 \%$ lupin seed. ${ }^{*} p<0.05$; ${ }^{* *} p<0.01$.

${ }^{1} \%$ of live weight; ${ }^{2}$ - intraabdominal fat and fat adherence gizzard. 
turkey broiler ( $40 \%$ of the feed weight) can have a negative impact of some performance indicators and carcass value. The results are consistent with the findings reported by Egorov et al. (2001), which noticed that the best results were obtained when lupine flour was up 20\% from the structure of the chicken broilers diet. Similar studies, which reached at the same findings were run by RothMaier and Paulicks (2003) and Suchy et al. (2010). Suchy et al. (2010) reported that by replacing nitrogen in soybean at a rate of up to two-thirds do not affect the content in protein and fat of breast and thigh muscles, but it only increases the crude ash contents in the chest.

\section{CONCLUSION}

Substituting soy protein meals in the food of turkey broilers by provisioning alkaloids free white lupine seeds in the structure of mixed fodder at a rate of up to $30 \%$ (\% by weight) has no adverse effect on weight gain, the degree of food recovery, slaughter and carcass quality indices; however it has the advantage that feed costs per $1 \mathrm{~kg}$ gain in weight decreases by up to $10.78 \%$.

Acknowledgements. This work was supported by a grant of the Romanian National Authority for Scientific Research, CNDI - UEFISCDI, project number PN-II-IN-CI-2013-1-0080.

\section{REFERENCES}

1. Brenes A, Marquadt RR, Guenter W, Rotter BA (1993) Effect of enzyme supplementation on the nutritional value of raw, autoclaved, and dehulled lupins (Lupinus albus) in chicken diets. Poultry Sci. 72: 2281-2293.

2. Egorov IA, Chesnokova NY, Takunov IP (2001). Feed value of lupin for broiler chickens and laying hens. Kormoproizvodstvo 1: 28-30.

3. Froidmont E, Beckers Y, Dehareng F, Théwis A, BartiauxThill N (2004). Lupin seed as a substitute to soybean meal in broiler chicken feeding: incorporation level and enzyme preparation effects on performance, digestibility and meat composition. www.eaap.org/Previous_Annual_ Meetings/

4. Kocher A, Choct M, Hughes RJ, Broz J (2000). Effect of food enzymes on utilisation of lupin carbohydrates by broilers. Brit. Poultry Sci. 41:75-82.

5. Lettner F, Zollitsch W (1995). Lupins in broiler feeds. Forderungsdienst 43: 285-288.

6. Mierlita D (2012). Studies on cultivation suitability and nutritional characterization of lupine alkaloid- free varieties. Analele Univ. din Oradea, Fascicula: Ecotoxicologie, Zootehnie si Tehnologii de industrie alimentara, XI (B): 501 - 507.

7. Nalle CL, Ravindran V, Ravindran G (2010). Evaluation of Faba Beans, White Lupins and Peas as Protein Sources in Broiler Diets. International J. Poultry Sci. 9 (6): 567-573.

8. Nalle CL (2009). Nutritional Evaluation of Grain legumes for Poultry. Ph.D. Thesis. Massey University, Palmerston North, New Zealand.

9. Olver MD, Jonker A (1997). Effect of sweet, bitter and soaked micronised bitter lupins on broiler performance. Br. Poult. Sci., 38: 203-208.

10. Pallant J (2007). SPSS Survival Manual, Mc Graw Hill, Open University Press Aplicatii, http://www.allenandunwin. com/spss3/default.htm

11. Roth-Maier DA, Paulicks BR (2003). Feeding and nutritional value of sweet blue and yellow lupin seed (Lupinus angustifolius L., Lupinus luteus L.) for broiler chicks. Arch Geflügelkd 67: 175-178.

12. Sipsas S, Glencross B (2005). Implications of variability amongst Lupin cultivars in processing. Proceedings of the third workshop for Seeding a Future for Grains in Aquaculture Feeds. Fremantle, Western Australia: 8-13.

13. Sitko VA, Čermák B (1998). Influence of lupin seed on performance and meat quality of broilers. Sborník Zemědělské Fakulty Jihočeské Univerzity, České Budějovice: Zootechnická řada 15: 3-9.

14. Steenfeldt S, Gonzalez E, Knudsen KEB (2003). Effects of inclusion with blue lupins (Lupinus angustifolius) in broiler diets and enzyme supplementation on production performance, digestibility and dietary AME content. Anim. Feed Sci. Technol. 10:185-200.

15. Straková E, Suchý P, Večerek V, Šerman V, Mas N, Jůzl M (2006). Nutritional composition of seeds of the genus Lupineus. Acta Vet Brno 75: 489-493.

16. Suchý P, Straková E, Herzig I, Steinhauser L, Vopálenský J, Kroupa L (2010). Effect of Replacing Soybean Meal with Lupin Seed-based Meal in Chicken Diet on Performance, Carcass Value and Meat Quality. Acta Vet. Brno, 79: 195202.

17. Sujak A, Kotlarz A, Strobel W (2006). Compositional and nutritional evaluation of several lupine seeds. Food Chem 98: 711-719.

18. Teixeira AS, Dos R (1995). Replacement of soyabeans by lupins (Lupinus luteus) in the feeding of broiler fowls. Rev Portug Ciênc Veter 90: 20-28.

19. Vecerek V, Suchý P, Straková E, Machácek M (2008). Nutritive composition of seeds of the lupin varieties registered in the Czech Republic. IN J.A. Palta and J.B. Berger (eds). 2008. 'Lupins for Health and Wealth' Proceedings of the 12th International Lupin Conference, 14-18 Sept. 2008, p: 123-126, Fremantle, Western Australia. International Lupin Association, Canterbury, New Zealand. 